\title{
Consequences of brown bear viewing tourism: a review
}

Vincenzo Penteriani ${ }^{\mathrm{a}, \mathrm{b}} * \dagger$, José Vicente López-Bao ${ }^{\mathrm{a} *} \uparrow$, Chiara Bettega ${ }^{\mathrm{a}}$, Fredrik Dalerum $^{\text {a,c,d }}$, María del Mar Delgado ${ }^{a}$, Klemen Jerina ${ }^{e}$, Ilpo Kojola ${ }^{f}$, Miha Krofel ${ }^{e}$, Andrés Ordiz ${ }^{\mathrm{g}}$

${ }^{a}$ Research Unit of Biodiversity (UMIB, UO-CSIC-PA), Oviedo University - Campus Mieres, 33600 Mieres, Spain

${ }^{b}$ Department of Conservation Biology, Estación Biológica de Doñana, C.S.I.C., c/Américo Vespucio s/n, 41092 Seville, Spain

'Department of Zoology, Stockholm University, 10691 Stockholm, Sweden

${ }^{\mathrm{d}}$ Mammal Research Institute (MRI), Department of Zoology and Entomology, University of Pretoria, Private Bag X20, Hatfield, 0028 South Africa

${ }^{\mathrm{e}}$ Department of Forestry and Renewable Forest Resources, Biotechnical Faculty, University of Ljubljana, Večna pot 83, SI-1001 Ljubljana, Slovenia

${ }^{\mathrm{f}}$ Natural Resources Institute Finland (Luke), Box 16, Fl-96301, Rovaniemi, Finland

${ }^{\mathrm{g}}$ Department of Ecology and Natural Resource Management, Norwegian University of Life Sciences, Postbox 5003, NO-1432 Ås, Norway

*Corresponding authors:

VP (penteriani@ebd.csic.es)

JVLB (jv.lopezbao@gmail.com)

( $\uparrow$ these authors contributed equally to this work)

Corresponding author for manuscript correspondence

Vincenzo Penteriani, Research Unit of Biodiversity (UMIB, UO-CSIC-PA), Oviedo

University - Campus Mieres, 33600 Mieres, Spain. Phone number: +34 650432446.

Email: penteriani@ebd.csic.es 
Many countries promote wildlife observation as part of ecotourism offerings. The brown bear Ursus arctos is among the most targeted species for ecotourism in North America and Europe, making it an ideal candidate to examine the consequences of wildlife viewing upon the species. As bear viewing often occurs in sensitive places where bears congregate for mating, rearing young and/or feeding, it is important to evaluate potential positive and negative effects of different viewing practices. Here we reviewed available information on bear viewing practices and their effects on bears, people and ecosystems. Behavioural, physiological and ecological aspects related to bears are reviewed from three different perspectives: ecotourism consequences for bears, direct bear-human interactions and social impacts of bear ecotourism. Because bear viewing can have positive and negative impacts on both bear populations and bear-human interactions, it is important to carefully evaluate every practice associated with bear viewing at a local scale. Because bear populations around the world have diverse population statuses and different management regimes, successful procedures and rules effective in one place do not guarantee that they will be adequate elsewhere. Effective management of bear viewing practices requires a better understanding of the consequences for bears, the mechanisms behind observed bear reactions to humans, and the results of bear habituation. Because inappropriate bear viewing practices can lead to processes such as foodconditioning and habituation, which can have serious consequences for both people and bears, regulations on bear ecotourism are urgently needed to minimize unintended consequences of bear viewing practices.

Key words: Ursus arctos, feeding site, grizzly bear, management, viewing site, habituation, food-conditioning, ecotourism

Running head: Ecotourism effects on brown bears 


\subsection{Wildlife observation as a growing form of ecotourism}

Ecotourism is rapidly growing as a commercial activity and is currently considered as one of the world's biggest industries (Blangy and Mehta, 2006; Knight 2009; Geffroy et al., 2015). For example, Starmer-Smith (2004) estimated that by 2024 ecotourism will represent $5 \%$ of the global holiday market, and the number of ecotourists is growing approximately three times faster than that of conventional tourists (Das and Chatterjee, 2015). The world's protected areas presently receive ca. 8 billion visits per year, which generates around US $\$ 600$ billion annually in direct incountry expenditure and US $\$ 250$ billion in consumer surplus (Balmford et al., 2015). Ecotourism activities, defined as the "responsible travel to natural areas that conserves the environment, sustains the well-being of the local people, and involves interpretation and education" (TIES, 2015) may have both positive and negative consequences for the environment and the conservation of target species, as well as for humans (Fig. 1) (Boyle and Samson, 1985; Taylor and Knight, 2003; Steven et al., 2011; Ghosh and Uddhammar, 2013; Sato et al., 2013; Das and Chatterjee, 2015; Mossaz et al., 2015; Bentz et al., 2016; Tolvanen and Kangas, 2016).

There is much hope for ecotourism to promote and support biodiversity conservation, but several examples illustrate the failure of some ecotourism practices (Das and Chatterjee, 2015). Consequently, environmental managers are confronted with complex decisions regarding where, when and how to promote, regulate or limit ecotourism practices (Buckley and Pabla, 2012). Trade-offs continuously emerge among the non-consumptive use of nature, wildlife conservation and the negative consequences of ecotourism, such as wildlife disturbance and habitat degradation. Moreover, other factors also interact with ecotourism, such as the consumptive use of nature (e.g. trophy hunting tourism) or other forms of tourism (nature-based or rural tourism) (Reynolds and Braithwait, 2001). It is therefore surprising that relatively little research has focused on assessing the potential trade-offs associated with ecotourism activities.

Organised viewing of wildlife is one of the most common forms of wildliferelated ecotourism, and it mainly targets charismatic species that are large and rare (Shackley, 1996; Okello et al., 2008; Cong et al., 2014; Gallagher et al., 2015; Grünewald et al., 2016). Currently, the opportunities for tourists to observe animals continue to increase and wildlife observation is becoming increasingly popular (e.g. Orams, 2002; Geffroy et al., 2015). This increasing popularity occurs in the broader context of the increasing demand to interact with nature (Jenner and Smith 1992). Getting close to animals contributes to the feeling that people are communing with nature and some argue that such a feeling is important in a heavily urbanized world (Orams, 2002).

\subsection{Brown bear viewing business}

Besides large mammal ecotourism in Africa (Lindsey et al., 2008; Okello et al., 2008), the brown bear (Ursus arctos) viewing is among the commons practices of wildlife related ecotourism (Skibins et al., 2012; Fortin et al., 2016). Here, we use term 
'brown bear' to refer to both European and North American brown bears. For example, in Alaska, USA, tourists are willing to pay more to view brown bears than any other Alaskan wildlife (Miller and McCollum, 1997), and in Denali National Park, Alaska, grizzly bear observations yield higher levels of wildlife viewing satisfactions compared to other species (Skibins et al., 2012). This has resulted in the rapid growth of the bear viewing industry (DeBruyn et al., 2004; Fortin et al., 2016). Bear viewing and photography were already common in Yellowstone National Park at the beginning of the last century, with bears, including American black bears (Ursus americanus), being regularly fed by people to promote viewing(Fig. 2). Since those earlier times, business income and visitation rates of bear viewing areas have increased rapidly, with some sites experiencing a doubling in visitation rates each year and an expansion into previously undisturbed areas (Rode et al., 2007). In addition, attracting brown bears by means of artificial feeding sites is becoming a common practice in Europe as well, e.g. at the Finnish-Russian border, where about 4,000 visitors arrive annually to observe bears (Eskelinen, 2009; Kojola and Heikkinen, 2012). Out of 235 bear viewing opportunities offered online in North America $(n=138)$ and Europe/Russia $(n=97$; Supplementary Material Table A1), artificial feeding was detected in $57 \%$ of the European bear viewing sites, which represents $23 \%$ of the 235 viewing sites.

Bear viewing provides economic benefits to ecotourism companies, as well as to hotels, restaurants, shops and other gateway-community businesses that profit from the tourists attracted to an area for bear ecotourism. For example: (1) ca. €1 million tourists visited bear viewing enterprises in Finland between late spring and early autumn (Eskelinen, 2009); and (2) bear viewing within the Great Bear Rainforest (British Columbia, Canada; Center for Responsible Travel, 2014) represents a significant economic activity for local companies in this area, handling a total of 11,369 bear viewing visitors in 2012 and enabling the employment of several hundred people in occupations such as naturalist guides, housekeeping and chefs. In 2012, employers related to bear viewing activities earned $\$ 4.9$ million, and visitors in the Great Bear Rainforest spent $\$ 15.1$ million on bear viewing, of which $\$ 14.1$ million went to bear viewing businesses. In 2012, bear viewing companies in the Great Bear Rainforest generated more than 12 times more in visitor spending than bear hunting (Center for Responsible Travel, 2014).

\subsection{Brown bear viewing practices}

Bear viewing can take place from either permanent or temporary viewing sites. Permanent viewing sites usually include hides located in the immediate vicinity of artificial feeding sites (e.g. Finland, Romania and Slovenia in Europe; Fig. 3A-3B) or vantage points associated with natural feeding sites or some other locations with predictable occurrence of bears (e.g. Brooks Falls in the Katmai National Park, Alaska, US, boat-based bear viewing in British Columbia, Canada; Fig. 3C-3D). Temporary viewing sites are typically opportunistic, and for instance include (Fig. 3E and 3F): (1) 'bear jams', which occur when the vehicles of people watching bears obstruct traffic (Haroldson and Gunther, 2013; e.g. Yellowstone National Park, US); (2) observation sites targeting female bears with cubs of the year, which have limited mobility and are more diurnal, and therefore more visible than other bears (Ordiz et al., 2007); and (3) bear mating areas and natural bear feeding sites such as berry-rich mountain slopes 
(e.g. in the Spanish Cantabrian Mountains and the Italian Abruzzo Apennines), which are sometimes located in areas repeatedly used by bears in consecutive years (Fernández-Gil et al., 2006). Consequently, bear viewing sometimes occurs at close distances to sensitive places where bears congregate for mating, rearing of cubs and/or feeding.

Our purpose is to review the available information on bear ecotourism practices and their effects (Fig. 1) in order to inform the emerging debate on the suitability of bear ecotourism, and promote responsible practices and regulations. In particular, we: (i) identified potential impacts of this practice on bears, (ii) highlighted the complex socio-economic system in which bear ecotourism is framed; and (iii) identified crucial factors that need to be taken into account for appropriate management of bear viewing. We focused on the effects on bears (behaviour and physiology), ecosystems (i.e. ecological impact), bear-human interactions and human societies and communities.

\section{Methods}

To select articles for our review, we used Google Scholar and Thomson Reuters 'Web of Science' databases. We conducted the literature review (winter 2015 and, then, spring 2016) using a broad range of search terms that represent the variety of ways in which bear viewing activities may be included. Thus, the terms 'bear' and 'grizzly' were combined with the following terms (in alphabetical order): 'human interactions', 'people interactions', 'photography', 'ecotourism', 'feeding', 'observation', 'tourism', 'viewing', and 'watching'. We also searched in the literaturecited sections of all retrieved articles. All publications were categorized according to their focus on bear viewing activities: (a) consequences for bears ( $n=32$ papers); (b) bear-human interactions ( $n=14$ papers); and (c) consequences for human communities and societies ( $\mathrm{n}=5$ papers).

The locations and main features of bear viewing practices of current bear viewing sites in North America and Europe/Russia have been summarised in Table A1 (Supplementary Material). The table was built by searching on Google for 'brown bear/grizzly watching', 'brown bear/grizzly viewing', 'brown bear/grizzly photography' and 'brown bear/grizzly observation' + all the European countries and North American states were brown bears and grizzlies are present. For each search term, we checked the first 5 Google pages because information on viewing activities was scarce after them. Because the exact location of the viewing sites was generally imprecise, several online sites might actually advertise the same viewing location.

\section{Consequences for bears}

From the perspective of the potential consequences of bear ecotourism on brown bears and ecosystems, it is important to separate viewing sites without artificially provided food from those associated with artificial feeding. The spatially and temporally predictable presence of an artificial food resource at feeding sites has the 
potential to affect bears in multiple ways. The extensive body of literature on the impacts of supplemental feeding on animal ecology, behaviour and demography is informative on the potential consequences of bear feeding sites (e.g. Boutin, 1990). Moreover, in contrast to viewing sites without artificial feeding, where people are often visible, bear observation at feeding sites usually happens from hides that are accessed in a discrete way at hours when bears are not present, in an attempt not to disturb individuals in the immediate vicinity of the feeding sites (Eskelinen, 2009). We are aware that other factors, such as the number of visitors, spatio-temporal regulations of the activity or human-bear visual contacts and human smell may also be influential. However, to date, available information on the consequences of the abovementioned factors is still limited (e.g., information about the number of visitors in reported bear viewing sites is largely lacking, Supplementary Material Table A1). Therefore, we focused our review on the effects of bear viewing at sites without artificial feeding compared to the effects associated with the artificial feeding of bears. However, it is worth noting that even if we preferred to split the evidence from viewing sites with/without artificial feeding, it doesn't necessarily mean that the evidence presented is mutually exclusive (in relevance) to each section.

\subsection{Viewing sites without artificial feeding}

\subsubsection{Behavioural consequences}

The temporal and spatial predictability of many of the viewing sites (Supplementary Material Table A1), such as regulated North American viewing sites where bears concentrate during Pacific salmon (Oncorhynchus spp.) runs (Fig. 3C), might enable bears to develop adaptive behavioural responses that would reduce disturbance effects (Rode et al., 2006a). Brown bears may leave areas because of disturbances from sudden encounters with humans (Ahlén, 1976), and experimental approaches to radio-collared brown bears have shown that bears often flee and seek denser vegetation cover after encounters with people (Moen et al., 2012; Sahlén et al., 2015). Direct bear-human encounters alter the daily movement patterns of bears (e.g., Naves et al., 2001), which reduce activity during daytime and increase it during the night (Olson, 1998; Rode et al., 2006a, 2007), an effect that is most visible during the first two days after encounters, but which may last for a week in some cases (Ordiz et al., 2013). Therefore, bear displacement from viewing sites may be reduced in areas where bear viewers behave predictably because bears may adapt to predictable patterns of human activity (Wilker and Barnes, 1998; Fischbach and Reynolds, 2005; Tollefson et al., 2005; Rode et al., 2007). However, even predictable activity of people may cause disturbance that can affect bear foraging patterns, mating behaviour, space use and activity. Since such disturbance may affect individual survival and fitness (Rode et al., 2006a), this issue deserves further attention. For example, bears constrained to using resources close to viewing sites may exhibit increased vigilance (Braaten and Gilbert, 1987; see also Dycka and Baydack, 2004 and Andersen and Aars, 2005 for polar bears Ursus maritimus) and a reduction in time devoted to behaviours potentially affecting fitness (e.g. foraging, mating, caring for young; Chi and Gilbert, 1999; Nevin and Gilbert, 2005a; Rode et al., 2006a). 
The existence of a disturbance effect on bears can be exemplified from the observation that bears are often present in lower numbers and/or for shorter periods of time when exposed to bear viewing (MacHutchon et al., 1995; Fischbach and Reynolds, 2005; Rode et al., 2007; Smith and Johnson, 2004; Barnes and Wilker, 2000; Barnes, 2006). For instance, fewer bears are present at coastal foraging and salmon absent (Turner, 2012). More generally, bears in areas of high human activity appear to adopt a two-fold strategy: (1) avoiding humans if resources can be accessed at alternative times/locations, and/or (2) concentrating foraging in the presence of humans when resource availability and/or quality are high. In this way bears may maximize foraging efficiency in order to compensate for reduced total time spent foraging (Rode et al., 2006a).

The tolerance level of bears to the presence of people at viewing sites also depends on bear density. Brown bears in denser populations show higher tolerance towards people and other bears compared to bears in lower density populations (Smith et al., 2005). On the other hand, viewing sites may also lead to bear habituation, i.e. the loss of human avoidance and escape responses (Smith et al., 2005). Habituation is a process involving a reduction in response over time as individuals learn that there are neither adverse nor beneficial consequences of the occurrence of the stimulus, which in this case is human presence (McCullough, 1982; Whittaker and Knight, 1998). Habituation and tolerance to humans may also occur in areas with low bear density and reduced opportunity for bear-to-bear tolerance, i.e. when the likelihood of human contact is high due to the large number of visitors. A typical case is represented by Yellowstone National Park, USA, where 'bear jams' often occur, but do not aversively condition the bears to avoid roadsides (Herrero et al., 2005; Haroldson and Gunther, 2013). For instance, in 2002 alone, Yellowstone National Park recorded 692 bear jams, 279 of them involving brown bears, and since 1990 there have been over 3,000 documented bear jams in Yellowstone, over a third of them involving brown bears (Herrero et al., 2005). Bears appear to have learned that temporal aggregations of large numbers of park visitors near roads are not a threat and thus they tolerate people at close distances in exchange for access to natural food resources found along road corridors (Haroldson and Gunther, 2013). Nevin and Gilbert (2005a) also suggested that bears were sufficiently habituated to olfactory, auditory, and visual cues from people at the viewing locations that they may approach areas frequented by tourists without regard to the people present.

Viewing bears, and especially human-habituated bears, can also have a cost, for both bears and humans. Potential risks for bears include (Herrero et al., 2005): (1) bears near roadsides or railways could be at higher risk of being injured or killed in vehicle collisions; (2) habituated bears could be at higher risk of being killed by people; (3) bears near roads could be at higher risk of being fed by people or access human food themselves and eventually become food-conditioned animals; and (4) despite regulations, habituated bears could be at higher risk of being approached at close range by people for better photographs or viewing, resulting in a higher risk of human injuries as a consequence of inappropriate human behaviours (Penteriani et al., 2016), which in turn leads to bear harassment or even bear removal. On the other hand, potential risks to humans include: (1) close proximity of bears to people may 
encourage inappropriate, even illegal, acts (e.g. poaching); (2) presence of habituated bears may increase the potential for human injuries or fatalities; and (3) habituated bears can cause traffic jams and potentially collisions/traffic accidents.

Bears show huge individual variability in their behaviour and, thus, behavioural consequences may be very different from bear to bear and, therefore, difficult to predict (Steyaert et al., 2014). The consequences of viewing sites for bears can also be sex- and age-dependent. Sexual dimorphism seems to impose significant time constraints on the foraging behaviour of larger adult males due to changes in foraging activities when in the vicinity of a viewing site. Males may alter their temporal foraging patterns by foraging more at night and less during the day when humans are present (Rode et al., 2006a). Thus, because bears cannot forage continuously, but must feed in distinct bouts separated by periods of digestion and defecation (Rode et al., 2001), prevalent night-time foraging may prevent adult males from having sufficient time to meet their nutritional needs (Rode et al., 2006a). On the other hand, different sexual responses to bear viewing can also be beneficial for some bear age and sex classes. Less dominant, often younger bears or vulnerable females with cubs avoid dominant bears either by foraging during daytime, when disturbance from people is higher, or segregating spatially from dominant bears, which can explain the proximity of young bears or females with cubs to people (e.g. Nellemann et al. 2007; Elfström et al. 2014 $a, b, c)$. For example, avoidance of bear viewing sites by mature males in British Columbia, Canada, created temporal refuges for subordinate bears, as well as enhanced feeding opportunities and cub safety (Nevin and Gilbert, 2005a; Elmeligi and Shultis, 2015; Cristescu et al., 2016). Peaks of activity of females with cubs occurred when neither people nor adult males were present, supporting the possibility that humans might not be perceived as entirely risk free (Nevin and Gilbert, 2005a). However, there was no reduction in feeding by females with cubs when people were the only potential source of risk at the viewing sites (Nevin and Gilbert, 2005b). Similar responses have also been observed in the use of bear feeding sites in Slovenia and Finland (authors' unpublished data).

Finally, a recent study focusing on the potential population-level effects of bear viewing, suggested that bear displacement may affect bear health, reproduction and survival. These effects are likely associated to decreased nutritional intake and increased energetic costs (Fortin et al., 2016). The regulation and reduction of the levels of recreational activities (e.g. fishing, hunting and bear viewing) have been observed to have positive effects on nutritional intake, energetic costs, reproduction and survival (Fortin et al., 2016).

\subsubsection{Physiological and ecological consequences}

To our knowledge, there are no specific studies investigating possible physiological and ecological consequences of viewing activities on bears, although environmental factors such as human presence are potential sources of physiological stress (von der Ohe et al., 2004). In several other species, such as elk Cervus canadensis, human disturbance has been found to correlate with faecal glucocorticoid levels (Millspaugh et al., 2001). Stress can alter behaviour, reduce resistance to disease and, thus, may affect population performance (Millspaugh and Washburn, 2004). Because human presence and human activities affect daily activity patterns of bears 
(e.g., Ordiz et al., 2012, 2013, 2014) and also act as a stressor (Støen et al., 2015), bear viewing with or without feeding sites can add to the existing level of disturbance induced by people in human-dominated landscapes. The displacement of bears from areas at or around viewing sites could also locally decrease ecological functions performed by bears (reviewed below, see section 3.2.3).

\subsection{Viewing sites with artificial feeding}

\subsubsection{Behavioural and demographic consequences}

The provision of artificial food to bears has the potential to impact bear behaviour in several ways (Fig. 1) (Orams, 2002; Penteriani et al., 2010; Kojola and Heikkinen, 2012; Dubois and Fraser, 2013; Massé et al., 2014; Steyaert et al., 2014; Kavčič et al., 2015; Krofel et al., in press). The primary expected effects include disruption of daily and seasonal movement patterns, changes in circadian activity (e.g. Ayres et al., 1986) and disruption of denning behaviour (Krofel et al., in press). The presence of artificial feeding sites can also locally increase bear densities and their activity (López-Bao et al., 2011; Jerina et al., 2012; Cozzi et al., 2016), which may increase the interaction rate among bears (Dolšak, 2015). Concentrations of bears at feeding sites and differential use of artificial food according to individual attributes may also determine spatial and/or temporal avoidance of feeding sites by females with cubs to avoid potentially dangerous interactions with males (Dolšak, 2015; see also López-Bao et al., 2009, 2011, for similar effects of artificial food in the Iberian lynx, Lynx pardinus). In several regions of Europe, where feeding sites are also used for bear hunting (Kavčič et al., 2013, 2015), temporal segregation patterns in the use of feeding sites has been observed among different age-sex classes, with more dominant bears typically arriving later during the night, when encounter rates with humans are lowest (Dolšak, 2015).

Steyaert et al. (2014) showed that individual traits may influence bear utilization of feeding sites, suggesting that it may not necessarily be feeding sites per se that cause a change in behaviour, but that they are utilized more frequently by individuals with specific behaviours. This proposition is supported by observations of large individual variation in nuisance behaviour (Majić Skrbinšek and Krofel, 2015) and it contradicts the hypothesis of supplementary feeding causing nuisance behaviour. Indeed, Kojola and Heikkinen (2012) found no evidence that bear viewing associated with bear feeding sites trigger nuisance-bear cases in Finland and same was observed in Slovenia (Steyaert et al., 2014). On the other hand, we have observed that some bears frequently approach feeding sites as soon as they detect the arrival of a person carrying food, which suggests that bears may learn to connect the presence of humans and food provisioning at viewing sites (authors' unpublished data).

Although the consumption rates of artificial and natural foods may be interrelated (López-Bao et al., 2010; Kavčič et al., 2015), the provision of artificial food to bears, which is a common practice in Europe (Supplementary Material Table A1), has the potential to create food-conditioned bears. In Slovenia, food from feeding sites (mainly corn) represents $34 \%$ of the annual dietary energy ingested by the local bear 
population (Kavčič et al., 2015) and on average bears spend 8\% of their time at the feeding sites (Krofel et al., in press; Fig. 3B). Nevertheless, when feeding is done properly as a management measure, it has the potential to decrease the level of bearhuman conflicts (Stringham and Bryant, 2015; Kavčič, 2016), probably by buffering variation in the availability of natural foods (Bautista et al., 2016). In addition to behavioural changes, artificial feeding of bears may affect several life history traits and demographic parameters. For example in Slovenia, intensive supplemental feeding of bears was suggested to be the reason for the highest known reproductive rates for this species and corresponding intensive culling aimed to prevent the population growth (Krofel et al., 2012a; Reding, 2015). It must however be noted, that these effects are the result of a very intensive national supplemental feeding program, which is unlikely to be practiced on this level for the sole purpose of ecotourism, although some of the feeding sites in Slovenia and other countries are also used for bear viewing.

\subsubsection{Physiological consequences}

Supplementary food provided to bears may be nutritionally unfavourable. For instance, in some areas of eastern Finland (Karelia), food at feeding sites created for bear viewing purposes is composed of dog pellets and farmed salmon Salmo salar (Eskelinen, 2009; Penteriani et al., 2010; Fig. 3A). The continued consumption of farmed salmon may expose bears to a variety of persistent bioaccumulative contaminants, particularly organochlorines, which have been linked to cancer and abnormal mental development in humans (Hites et al., 2004). Moreover, animal byproducts, antibiotics, pesticides, artificial colours and chemical preservatives in lowquality dog pellets might have harmful effects associated with chronic disease (e.g. dehydration, diabetes, foetal abnormalities, liver damage, obesity; Penteriani et al., 2010). In countries of central and eastern Europe, large amounts of corn and livestock carrion are used as supplemental foods for bears, for diversionary feeding (i.e. provision of alternative foods in an attempt to divert bears away from sites or food sources where they could cause conflicts with people) and/or for hunting and bear viewing purposes (Kavčič et al., 2015). The impacts of supplemental feeding on bear health have been poorly studied, but it was observed that these practices strongly affect bear diet at the population level (Kavčič et al., 2015) and considerably shorten hibernation period (Krofel et al., in press). Indeed, a recent review on the effects of artificial feeding on wildlife found that $85 \%$ of the studies on feeding for ecotourism purposes found negative effects on animal health (Murray et al. 2016). The potential increment in the transmission of infectious diseases (Sorensen et al., 2014; Murray et al. 2016) through direct physical contact or indirectly through animals sharing food might also be expected as a consequence of increased densities of bears around feeding sites, and deserves further investigation.

\subsubsection{Ecological consequences}

In addition to direct consequences for bears, artificial feeding can also trigger indirect consequences at the ecosystem level. Bears can perform important ecological roles, such as dispersing seeds from fleshy-fruit plants (Wilson and Gende, 2004), increasing the flow of marine nitrogen to terrestrial ecosystems (Hilderbrand et al., 1999), limiting arthropod predators and ungulate herbivores (Zager and Beecham, 2006; Grinath et al., 2015), and reducing carcass availability for the predator and 
scavenger guilds (Krofel et al., 2012b; Allen et al., 2014). It has been suggested that the artificial feeding of bears could affect the consumption of natural foods, which might in turn affect the ecological functions of bears (Kavčič et al., 2015). To date, our understanding of the ecological consequences of bear artificial feeding is limited and further research is warranted. For example, a study in Slovenia demonstrated that the supplemental feeding of bears locally increased bear kleptoparasitism of prey remains from the Eurasian lynx Lynx lynx (Krofel and Jerina, 2016). This may cause further trophic cascades because lynx increase their predation rates on ungulates in response to the loss of kills to scavenging bears (Krofel et al., 2012b). An increase in interspecific interactions is also expected due to the shortened denning period of bears with access to artificial food (Krofel et al. in press). Finally, bear feeding sites are regularly used by other wildlife (authors' unpublished data) and this could have additional ecological side-effects, such as increased nest predation by predators attracted to feeding sites, similar to the consequences observed for ungulate feeding sites (Selva et al., 2014).

\section{Consequences for bear-human direct interactions}

Little information is currently available on the potential relationship between bear ecotourism and bear habituation to human presence. Habituation is assumed to occur when bears develop a tolerance of human presence at close distances (Herrero et al., 2005; Smith et al., 2005). Habituation is not an all-or-none response and varies widely among individuals (Steyaert et al., 2014). The habituation of bears to people will occur to the extent that the benefits of not reacting outweigh the perceived costs (Herrero et al., 2005). It is important to separate habituation from food-conditioning, in which food rewards may encourage undesirable bear behaviours, and preventing access to anthropogenic foods reduces the probability of risky encounters between bears and people (Herrero, 2002; Hopkins III et al., 2010). When a bear does not overtly react to a person nearby or it is observed close to settlements, it is often assumed to be human-habituated. However, the social organization of bears should be taken into consideration before to assume habituation, e.g. younger bears and females with cubs can use areas closer to people because they are avoiding dominant bears (Elfström et al. 2014 a,b,c), which often stay further away from human settlements (Nellemann et al. 2007).

To confirm habituation, repeated measures of response in individuals subjected to controlled repetition of the same stimulus are required (Smith et al., 2005; Hopkins III et al., 2010). Also, a bear showing habituation to human presence is not necessarily a dangerous individual, as demonstrated by the extreme cases of bear-to-human habituation observed at several bear viewing sites where a bear attack has never been recorded (Smith et al., 2005). For example, in Yellowstone National Park no roadside bear viewers have been injured by a bear, and at McNeil River Falls State Game Sanctuary, Alaska, in over 28 years and roughly 60,000 encounters between brown bears and people, bears have never caused an injury to humans (Alaska Department of Fish and Game, McNeil River, State Game Sanctuary and Refuge http://goo.gl/8j6YSA). In fact, some have argued that bear-to-human habituation is the main factor responsible for creating safe bear viewing at sites in Alaska (Aumiller and Matt, 1994; Whittaker and Knight, 1998). Evidence suggests that bears habituated to the presence 
of people are less likely to attack humans (Aumiller and Matt, 1994; Smith et al., 2005; Herrero et al., 2005; but see the recent fatal grizzly attacks to two hikers, e.g. http://goo.gl/IU5Pe8, Frey et al. 2011, Wilmot et al. 2016) (Supplementary Material Table A1).

Interestingly, few bear viewing sites report strict rules for tourists (at least in the web pages promoting bear viewing -see Supplementary Material Table A1because rules might also be explained to visitors on site or at the time of booking): (a) only 2 sites (1\%) specify a minimum security distance from bears; (b) in only 3 sites $(1.3 \%)$ there is a restriction in the number of people per day, whereas other 74 (32\%) sites specify the maximum size of the groups; (c) 151 of the recorded sites (64.2\%) specify the period of the day/year, mostly not as a restriction but as the best time to watch bears; and (d) 46 sites (20\%) give general security rules, 16 in Europe (7\% of the total, $17 \%$ of the European sites) and 30 in North America (13\% of the total, $22 \%$ of the North American sites). The use of bear spray is never mentioned in the European sites, whereas in North America 5 sites specify it is provided by guides and in 2 sites its use is highly recommended.

Out of the 235 bear viewing sites we compiled, we only found three cases of bear attacks on humans in and around the same areas for bear viewing sites (i.e. in $1.3 \%$ of the bear viewing areas; Supplementary Material Table A1). Furthermore, these attacks were not directly related to the bear viewing practice. Two victims were hikers, and in the last case the guides of a hiking excursion in Alaska were attacked after the group happened to stay between a female and her cub. These observations highlight that bear attacks on humans are often triggered by risk-enhancing human behaviours during recreational activities in bear areas (Penteriani et al., 2016).

The situation is completely different when food is provided directly by the tourists viewing the bears, encouraging these bears to become food-conditioned individuals. For example, bears fed by the visitors at Denali National Park, USA (Albert and Bowyer, 1991), Yellowstone National Park (Gunther, 1992) and other locations in North America have frequently attacked people in the past and have become a major safety concern for park visitors (Herrero, 2002) (Fig. 2).

\section{Consequences for human communities and societies}

\subsection{Consequences for local and regional economies}

Ecotourism is a rapidly growing industry of which wildlife viewing is becoming an integral and important component (Tapper, 2006). Economic benefits for local communities can be either direct or indirect. Direct benefits often come from employment directly related to the viewing activities, for instance by employment of guides or regulatory staff, or increased reserve fees related to the opportunity of seeing wildlife (Tisdell and Wilson, 2004; Lindsey et al., 2013; Richardson et al., 2014; UN World Tourism Organisation, 2014). Indirect economic benefits from wildlife viewing are much harder to estimate (Macmillan and Phillip, 2008). However, they may include benefits related to the presence of tourists, such as the need for accommodation or food, or the willingness to spend money in local stores. They may 
also include less obvious benefits related to the willingness to invest in local areas or regions.

There is a large body of literature highlighting the economic importance of brown bear viewing in North America. For instance, the ability to view bears along roads in the Yellowstone National Park appears to be positively associated with visitation rates, with increased employment opportunities and other economic benefits as a result (Richardsson et al., 2014). These economic benefits caused by the opportunity to see bears along roads within the park are estimated to outweigh the costs of managing traffic problems associated with bear watching activities. Similarly, the estimated value of wildlife viewing trips in Alaska that included sightings of bears were close to 1.5 times higher than the estimated value of the seeing the second highest terrestrial mammal, the grey wolf Canis lupus (Miller et al., 1998). Seeing bears has also been suggested to have economic prospects in Canada (Centre for Responsible Travel, 2014; Nevin et al., 2014). Estimates of direct economic benefits from bear viewing in other parts of the world are still scant or absent. Similarly, estimates of indirect effects of bear viewing is scant, and we highlight the need for economic valuation of bear viewing in Europe and Asia, as well as estimations of the indirect economic values of bear viewing worldwide.

\subsection{Consequences for human attitudes towards environmental values}

Despite a dramatic recent increase the awareness of the global environmental crisis (Dalerum, 2014), public appreciation of environmental issues are still poor in some sectors of society (Robelia and Murphy, 2012). While eco-tourists likely are more aware of environmental issues than a random subset of society (Tapper, 2006), environmental awareness is often not followed by pro-environmental behaviour (Kollmuss and Agyeman, 2002; Matutinovic, 2012). However, seeing wild animals and having first hand experiences with wildlife may have positive effects on proconservation behaviour (Tisdell and Wilson, 2001). Although we are not aware of any studies on the importance of such effects quantified from bear viewing, it is likely that bears may have similar effects, especially since they are often anthropomorphised and evoke strong emotional responses (Harding, 2014). Seeing bears in their natural habitat are often reported as a positive experience, and people who have seen bears are more likely of become ambassadors of good will for the species (Herrero et al., 2005). However, we stress that the importance of bear viewing for raising awareness about key environmental issues are still scant, and we urge for studies quantifying the potential for bear viewing to encourage and promote pro-environmental behaviour.

\subsection{Consequences for human welfare and well-being}

Although industrialization has brought undeniable benefits to humanity, associated processes such as urbanization and subsequent alienation from nature may also have negative effects on people (Lovelock, 2006). Therefore, and perhaps not surprisingly, there is ample evidence that interacting with nature has direct and measurable health benefits for modern humans (reviewed in Keniger et al., 2013), 
513 including reconnecting to previously lost spiritual values of humanity and our

514 environment (Taylor, 2010). Wildlife tourism is an important platform for facilitating

515 such interactions (Curtin and Kragh, 2014), and wildlife encounters may be particularly

516 effective in generating positive benefits for people (Curtin, 2009).

$517 \quad$ Seeing bears may provide important experiences for people (Herrero et al., 518 2005), and bears have strong symbolic values as indicators of pristine and wild areas 519 (Harding, 2014). Hence, in some cases bear encounters may define the wilderness 520 values of an area, rather than the characteristics of the area itself (Nevin et al., 2014).

521 For example, huge numbers of tourists congregated at the historic garbage dump522 based bear viewing in Yellowstone National Park to observe bears, despite the low 523 quality of the surroundings, especially if compared with the spectacular beauty of the 524 Park. Yet, brown bears may also invoke fear, mostly related a perception of the species 525 as dangerous and unpredictable (Johansson et al., 2012). Hence, it is important that 526 any bear viewing activities are accompanied by appropriate information campaigns, 527 both about the real risks of the activity as well as of how to appropriately interpret 528 bear behaviour as to minimize the likelihood of an aggressive encounter and a 529 negative experience (Aumiller and Matt, 1994).

\section{Discussion}

Although some brown bear populations in developed countries have been shown to successfully deal with human-dominated landscapes, e.g. in Europe (Chapron et al., 2014), the collective impact of ecotourism on bears remains unclear. The growing industry of bear viewing has caused some areas in North America to have experienced visitation increases exceeding $100 \%$ per year (Palmer, 2003). Yet, recent research suggests that bears perceive humans as a risk and respond with typical antipredator behaviours (Ordiz et al., 2011; Støen et al., 2015), such as changes in vigilance or displacement (Nevin and Gilbert, 2005a; Rode et al., 2006b), even at wellestablished bear viewing sites (e.g. Braaten and Gilbert, 1987; Olson et al., 1997; Chi, 1999).

Rode et al. (2006a) made two other important suggestions for regulations that should be implemented in the use of viewing sites, especially if they are located in close proximity to bears (from dozens to a few hundred metres). Firstly, human access to viewing areas should be controlled because group movements may result in lower numbers of bears using food resources, in contrast to when viewing groups are stationary. This practice could be less important if viewing sites are close to roads (where bears are accustomed to seeing people, but see also section 3.1.1, for the risks for bears using areas close to roads), or several hundred metres from the core areas of bear activity. The decline in vigilance behaviour when bears were more than $100 \mathrm{~m}$ away from people suggests that bears may continue their foraging and mating activities when viewing sites are located several hundred metres from them (Rode et al., 2006a). Finally, because human activity triggers morning departures of males (Nevin and Gilbert, 2005a), occasional cancellations of the earliest viewing sessions would permit this age/sex class to remain undisturbed. 
As highlighted by Fortin et al. (2016), we encourage managers to adopt actions oriented to reducing negative side-effects of bear ecotourism by identifying and protecting prime bear feeding habitats and cub-rearing places through seasonal (e.g. during the breeding period) or daily restrictions (e.g. in areas used by females with cubs-of-the-year), as well as to set context-specific regulations on the minimum distance between bears and viewing sites. This should be done in a dynamic way, adapting to location circumstances and the movement of bears, at least during the cub-rearing period and the mating season. In this regard, we urgently recommend that viewing sites targeting endangered bear populations should be placed at a conservative distance from key areas, for example in regions like the Cantabrian Mountains (Spain), Alps or Apennines (France and Italy), where forest cover is low (enabling viewing from large distances) and bear movements are less predictable than at feeding sites. Although a conservative suggestion of several hundred meters from areas of bear activity seems reasonable, research is needed to objectively set distances in different scenarios. Rode et al. (2006a) suggested that providing bears with adequate access to resources can be achieved through minimizing the displacement of bears caused by human activity by providing predictable human-free time periods. Bears in the proximity of tourists altered their temporal patterns to utilize those time periods that were consistently and predictably free of humans. Daily restrictions are applied in some of the bear viewing sites that we compiled, but not in majority of them (Supplementary Material Table A1). Although changes in temporal patterns of resource use by bears in response to viewing activities are relatively well-documented (Olson, 1993; Chi and Gilbert, 1999; Nevin and Gilbert, 2005a), Rode et al. (2007) showed that when bears changed the timing, rather than the location, of resource use, they did not increase travel or reduce resource use, suggesting that temporal changes may have negligible impacts on bear nutrition.

Though some displacements of bears due to the presence of a viewing site can occur with minimal nutritional effects, when estimating the impacts of human activity on local bear populations we should consider several specific, local factors such as (a) carrying capacity of the site relative to the existing bear population, (b) availability of alternative food resources, and (c) distance and energy needed to move to alternative food sources. However, spatiotemporal displacements of individuals still have the potential to alter breeding and negatively impact bear condition if resources cannot be utilized at other times or locations (Rode et al., 2007). The amount of human-free time periods during the day or within a given period should reflect local conditions and year-to-year variation in the availability of food resources. In general, based on available information, we encourage the application of consistent temporal restrictions of tourist visitation to viewing sites wherever feasible.

The bear's choice of whether or not to flee and the impact of that decision are crucial in evaluating the effects and sustainability of bear viewing. Effective viewing sites generally rely on individuals that are either unaware of human observation or habituated to human presence (Herrero et al., 2005). However, we still lack information on the motivations behind the decision of individuals to tolerate the presence of humans (Smith et al., 2005). In some situations it may be risky to abandon a given place because of the costs associated with fleeing in comparison to tolerating disturbance (e.g. female rearing cubs in an area free of males) (Elfström et al., 2014b). 
Also bears living in areas with higher human densities appear to have higher tolerance thresholds compared to bears from remote regions (Mohorović et al., in press). Thus, the increasing demand for bear ecotourism urgently calls for an understanding of the conditions causing bears to flee or stay around viewing sites, as well as the fitness consequences of these behaviours. These issues are important for evaluating the impacts of bear viewing practices on bear populations.

Nevin and Gilbert $(2005 a, b)$ have shown that appropriately managed bear viewing areas may bring direct benefits for the individuals viewed. They found that effective regulations (such as maximum number of people, viewing time schedule and visitor's behaviours) on human presence at high density feeding aggregations (e.g. during salmon runs) may enhance feeding opportunities for females with cubs. Regulations on bear viewing and their enforcement are urgently needed in many places to minimize unintended consequences of this practice (DeBruyn et al., 2004). In this regard, we suggest that the continuous presence of, or at least random checking by, official personnel (e.g. park ranger, tourist guide, wildlife officer, professional hunter, local police) or official volunteers controlling human behaviour is necessary in critical areas for bears. Of equal importance is the effective fining of visitors for not following the regulations on bear viewing (e.g., a photographer approaching too close to a bear). The presence of official personnel should be guaranteed, however, in all places where bears are viewed from a close distance, such as at salmon runs or artificial feeding sites. Bear responses, such as the decision to stay, exhibit stressrelated behaviours, or flee, are influenced by the behaviour of visitors at viewing sites (DeBruyn et al., 2004). Management policies should not overlook the education of visitors on-site, as rules are generally better followed when visitors understand the reasoning behind them. When viewing sites are in places where animals are observed from close distance or they are close to key areas for bears, we recommend that the presence of people should be concealed. While the use of concealed observatories or blinds is well-known to birdwatching and it is also found in other kinds of wildlife viewing, they are not often used for bear viewing (Knight, 2009). We also encourage development and application of guidelines for responsive bear viewing, similar to those developed for example in British Columbia, Canada (Commercial Bear Viewing Association of British Columbia; http://goo.gl/enuemb) or Dinaric Mountains, Slovenia and Croatia (Karamanlidis et al., 2016).

A common perception is that artificially feeding wildlife for recreational purpose does not conflict with conservation and may appear to be generally positive (Dubois and Fraser, 2013). However, animal feeding related to recreational activities has frequently been shown to have negative effects on wildlife (Orams, 2002; Corcoran et al., 2013; Dubois and Fraser, 2013; Barnett et al., 2016). Additionally, encouraging the feeding of bears can contribute to public misunderstanding about the overall risks of feeding large carnivores. Although there are no rigorous and detailed data to determine whether or not the establishment of feeding places for ecotourism purposes represents a risky practice (Kavčič et al., 2005; Kojola and Heikkinen, 2012), detrimental effects on bears may appear depending on local conditions and the types of food used to feed bears. Given several unwanted potential and actual side-effects of artificial feeding of bears, we strongly recommend to not use artificial feeding for bear ecotourism practices. This also builds upon the general recommendation that no 
artificial food should be available to bears in or near settlements and that artificial feeding in general should be avoided (Swenson et al. 2001). However, when feeding sites already exist for other purposes (e.g. baiting for hunting purposes or diversionary feeding for reducing human-bear conflicts), it may be possible to use them also for bear viewing (Karamanlidis et al., 2016), provided that all necessary measures to prevent bears from associating food with humans are applied, e.g. using automatic feeders for dispensing food and hides for visitors to prevent bears from detecting the presence of people. Beside this recommendation and the prohibition of direct feeding of bears by people, managers using artificial feeding for other purposes should consider the use of natural food sources that do not jeopardize bear health, limiting the amount of food provided to bears to minimize potential demographic effects, prohibiting feeding during winter to prevent disruption of denning behaviour and avoidance of areas sensitive for other species.

\section{Conclusions}

The variety of bear reactions to human activities reported in this review highlights that bear viewing can have strong implications, which are highly context dependent and therefore no single best prescription exists. Every area should be regarded as a separate case and the suitability, eventual locations and schedules of bear viewing should be evaluated on the basis of the conservation status of the bear population, local bear behaviour and density, as well as year-to-year availability of food resources and their use. There is no simple formula for determining how close people should be allowed to approach bears at viewing sites (Herrero et al., 2005) and the establishment of minimum distances deserves further investigation. Evidently, maintaining safe environments for bears and people at viewing sites calls for active management. This requires planning and financial resources. Objective contextdependent rules specifying the extent to which bears and people should interact in the framework of bear viewing are needed to inform managers, bear viewing company owners, policy-makers, and the general public. For example, in Finland, (1) because baiting is forbidden for hunting purposes, feeding for bear viewing should be stopped before hunting season starts; and (2) feeding sites should be far from sheep or calving grounds of semi-domesticated reindeer (Rangifer tarandus) because artificial food may attract bears to the proximity of sheep or reindeer. The establishment of these distances deserves further investigation.

Effective management of bear viewing practices requires a better understanding of the consequences for bears, the mechanisms behind observed bear reactions to humans, and the results of bear habituation. The factors behind potential problems associated with bear ecotourism are numerous: inappropriate human behaviours and the lack of education of visitors, poor planning of viewing site locations, infrastructures and public access to bear viewing sites, as well as improper management. Not every place inhabited by bears is necessarily suitable for bear viewing. For instance, bear populations around the world have diverse population statuses, from least concern to critically endangered, with very different management regimes, from being considered game species to being fully protected. Therefore 
successful procedures and rules effective in one place do not guarantee that they will be adequate elsewhere. For instance, viewing structures and regulations that have proven to be successful along a remote North American river, where dozens of bears congregate during salmon runs and can be viewed by tourists at close distance, may not be applicable to bear populations in Europe, where no such areas exist.

In some areas, high bear densities may increase tolerance for human presence and this understanding should be taken into consideration when establishing a bear viewing site. Individual variations of bear behaviours is yet another important component of the use of feeding sites and adaptability to bear viewing sites and should be considered as a crucial factor determining the development of bear viewing (Elmeligi and Shultis, 2015). Furthermore, behavioural strategies of bears close to viewing sites may vary among sex and age classes, resource availability and quality, as well as levels of perceived risk (Kie, 1999; Rode et al., 2006a). Therefore, the suitability of viewing sites should be evaluated on a case by case basis, but always with a vision of minimizing disturbance to bears and the environment, especially in sensitive areas for bears or other species.

Because human presence was shown to displace bears, especially if people are granted unrestricted access to close distance from bears, management closures seem essential in those areas where people and bears may have frequent contact (Coleman et al., 2013). In addition, precise time schedules of visits have been shown to be beneficial to bears (Coltrane and Sinnott, 2015) and should be applied whenever possible (few places apply temporal limitations nowadays; Supplementary Material Table A1). The ecosystem-level effects of these changes deserve further investigation as ecotourism activities and bear management should be managed from a broad perspective of ecosystem conservation (Grünewald et al., 2016; Krofel and Jerina, 2016).

\section{Acknowledgement}

We thank Stephen Herrero, Alexandros Karamanlidis, Dime Melovski, PierreYves Quenette and Nuria Selva for sharing useful information on bear ecotourism in their bear study area/country. We are grateful to three anonymous referees for useful comments that helped us to improve the manuscript. JVLB was supported by a 'Juan de la Cierva' research contract (JCl-2012-13066) from the Spanish Ministry of Economy and Competitiveness. MM Delgado was supported by a Spanish 'Ramón y Cajal' grant (RYC-2014-16263). KJ and MK were supported by the Slovenian Research Agency (J47362, P4-0059) and the Pahernik Foundation.

\section{References}

Ahlén, I., 1976. Forestry and the vertebrate fauna. Man and the boreal forest. Ecol. Bull. 21, 59-62. Swedish Nat. Sci. Res. Council. 
Albert, D.M., Bowyer, R.T., 1991. Factors related to Grizzly bear-human interactions in Denali National Park. Wildl. Soc. Bull. 19, 339-349.

Allen, M.L., Elbroch, L.M., Wilmers, C.C., Wittmer, H.U., 2014. Trophic facilitation or limitation? Comparative effects of pumas and black bears on the scavenger community. Plos One 9, e102257.

Andersen, M., Aars, J., 2005. Short-term behavioural response of polar bears (Ursus maritimus) to snowmobile disturbance. Kortrapportserie nr. 2, Norsk Polarinstitutt 2005, Troms $\varnothing$.

Aumiller, L.D., Matt, C.A., 1994. Management of McNeil River State Game Sanctuary for viewing of brown bears. Int. Conf. Bear Res. Manage. 9, 51-61.

Ayres, L.A., Chow L.S., Graber, D.M., 1986. Black bear activity patterns and human induced modifications in sequoia national park. Bears: Their Biology and Management 6, 151-154.

Barnes, V.G., Jr, Wilker, G.A., 2000. Brown bear activity, behavior, and response to public use at Karluk Lake, Alaska. Kodiak, Alaska, USA: U.S. Fish and Wildlife Service Report, USFWS.

Barnes V.G., Jr., 2006. Brown bear use, distribution, and composition under different public use management regimes at O'Malley River, Kodiak Island, Alaska. Kodiak, Alaska, USA: Kodiak National Wildlife Refuge, Job Completion Report.

Barnett, A., Payne, N.L., Semmens, J.M., Fitzpatrick, R., 2016. Ecotourism increases the field metabolic rate of whitetip reef sharks. Biol. Conserv. 199, 132-136.

Balmford, A., Green, J.M.H., Anderson, M., Beresford, J., Huang, C., Naidoo, R., Walpole, M., Manica, A., 2015. Walk on the Wild Side: Estimating the Global Magnitude of Visits to Protected Areas. PLoS Biology 13, e1002074.

Bautista, C., Naves, J., Revilla, E., Fernández, N., Albrecht, J., Scharf, A.K., Rigg, R., Karamanlidis, A.A., Jerina, K., Huber, D., Palazón, S., Kont, R., Ciucci, P., Groff, C., Dutsov, A., Seijas, J., Quenette, P.-I., Olszańska, P.-I., Shkvyria, M., Adamec, M., Ozolins, J., Jonozovič, M. and Selva, N., 2016. Patterns and correlates of claims for brown bear damage on a continental scale. J. Appl. Ecol. doi: 10.1111/1365-2664.12708.

Bentz, J., Lopes, F., Calado, H., Dearden, P. 2016. Managing marine wildlife tourism activities: Analysis of motivations and specialization levels of divers and whale watchers. Tourism Manage. Perspectives 18, 74-83.

Blangy, S., Mehta, H., 2006. Ecotourism and ecological restoration. J. Nature Conserv. 3-4, 233-236.

Boutin, S., 1990. Food supplementation experiments with terrestrial vertebrates: patterns, problems, and the future. Can. J. Zool. 68, 203-220. 
Boyle, S.A., Samson, F.B., 1985. Effects of nonconsumptive recreation on wildlife: a review. Wildl. Soc. Bull. 13, 110-116.

Braaten, A.M., Gilbert, B.K., 1987. Profile analysis of human-bear relationships in Katmai National Park and Preserve. Final Report National Park Service Contract No. CX 9700-4-0019, Utah State University, Logan, UT, 104pp.

Buckley, R.C., Pabla, H.S., 2012. Conservation: Tourism ban won't help Indian tigers. Nature 489, 33-33.

Center for Responsible Travel., 2014. Economic Impact of Bear Viewing and Bear Hunting in the Great Bear Rainforest of British Columbia. Washington, DC: Center for Responsible Travel.

Chapron, G. et al., 2014. Recovery of large carnivores in Europe's modern humandominated landscapes. Science 346, 1517-1519.

Chi, D.K., 1999. The effects of salmon availability, social dynamics, and people on black bear (Ursus americanus) fishing behavior on an Alaskan salmon stream. Ph.D. dissertation, Utah State University, Logan, UT.

Chi, D.K., Gilbert, B.K., 1999. Habitat security for Alaskan black bears at key foraging sites: are there thresholds for human disturbance? Ursus 11, 225-238.

Coleman, T.H., Schwartz, C.C., Gunther, K.A. Creel, S., 2013. Grizzly bear and human interaction in Yellowstone National Park: An evaluation of bear management areas. J. Wildl. Manage. 77, 1311-1320.

Coltrane, J.A., Sinnott, R., 2015. Brown bear and human recreational use of trails in Anchorage, Alaska. Hum. Wildl. Interact. 9, 132-147.

Cong, L., Wu, B., Morrison, A.M., Shu, H., Wang, M., 2014. Analysis of wildlife tourism experiences with endangered species: An exploratory study of encounters with giant pandas in Chengdu, China. Tourism Manage. 40, 300-310.

Corcoran, M.J., Wetherbee, B.M., Shivji, M.S., Potenski, M.D., Chapman, D.D., Harvey, G.M., 2013. Supplemental feeding for ecotourism reverses diel activity and alters movement patterns and spatial distribution of the southern stingray, Dasyatis americana. PLoS One 8, e59235.

Cozzi, G., Chynoweth, M., Kusak, J., Çoban, E., Çoban, A., Ozgul, A., Şekercioğlu, Ç.H., 2016. Anthropogenic food resources foster the coexistence of distinct life history strategies: year-round sedentary and migratory brown bears. J. Zool. doi:10.1111/jzo.12365.

Cristescu, B., Stenhouse, G.B., Boyce, M.S., 2016. Large omnivore movements in response to surface mining and mine reclamation. Sci. Rep. 6, 19177.

Curtin, S., 2009. Wildlife tourism: The intangible, psychological benefits of humanwildlife encounters. Curr. Iss. Tourism 12, 451-474. 
Curtin, S., Kragh, G., 2014. Wildlife tourism: reconnecting people with nature. Hum. Dim. Wildl. 19, 545-554.

Dalerum, F., 2014. Identifying the role of conservation biology for solving the environmental crisis. Ambio 43, 839-846.

Das, M., Chatterjee, B., 2015. Ecotourism: A panacea or a predicament? Tourism Manage. Perspectives 14, 3-16.

DeBruyn, T.D., Smith, T.S., Proffitt, K., Partridge, S., Drummer, T.D., 2014. Brown bear response to elevated viewing structures at Brooks River, Alaska. Wildl. Soc. Bull. $32,1132-1140$.

Dolšak, K., 2015. Sex - and age-related differences in the use of feeding sites by the brown bear (Ursus arctos). B. Sc. thesis. University of Ljubljana, Biotechnical Faculty, Ljubljana.

Dubois, S., Fraser, D., 2013. A framework to evaluate wildlife feeding in research, wildlife management, tourism and recreation. Animals 3, 978-994.

Dycka, M.G., Baydack, R.K., 2004. Vigilance behaviour of polar bears (Ursus maritimus) in the context of wildlife-viewing activities at Churchill, Manitoba, Canada. Biol. Conserv. 116, 343-350.

Elfström, M., Zedrosser, A., Støen, O.-G., Swenson, J.E., 2014a. Ultimate and proximate mechanisms underlying the occurrence of bears close to human settlements: Review and management implications. Mamm. Rev. 44, 5-18.

Elfström, M., Davey, M.L., Zedrosser, A., Müller, M., De Barba, M., Støen, O.G., Miquel, C., Taberlet, P, Hackländer, K., Swenson, J.E., 2014b. Do Scandinavian brown bears approach settlements to obtain high-quality food? Biol. Conserv. 178, 128-135.

Elfström, M., Zedrosser, A., Jerina, K., Støen, O.-G., Kindberg, J., Budic, L., Jonozovič, M., Swenson, J.E., 2014c. Does despotic behavior or food search explain the occurrence of problem brown bears in Europe? J. Wildl. Manage. 78, 881-893.

Elmeligi, S., Shultis, J., 2015. Impacts of Boat-Based Wildlife Viewing in the K'tzim-aDeen Inlet on Grizzly Bear (Ursus arctos) Behavior. Nat. Area. J. 35, 404-415.

Eskelinen, P., 2009. Karhut elinkeinona- millaisia ovat katselupalveluja tarjoavat yritykset? Riista- ja kalatalouden tutkimuslaitos, Helsinki, Finland.

Fernández-Gil, A., Naves, J., Delibes, M., 2006. Courtship of brown bears Ursus arctos in northern Spain: phenology, weather, habitat and durable mating areas. Wildl. Biol. 12, 367-373. 
Fischbach, A.S., Reynolds, J.H. 2005. Brown bear use of the proposed Kodiak National Wildlife Refuge O'Malley Bear Viewing Site: analysis of 1991, 1992, 1993, 1994 and 2003 study year observations. Job Completion Report. Kodiak, Alaska, USA: Kodiak National Wildlife Refuge and U.S. Fish and Wildlife Service.

Fortin, J.K., Rode, K.D., Hilderbrand, G.V., Wilder, J., Farley, S., Jorgensen, C., Marcot, B.G., 2016. Impacts of Human Recreation on Brown Bears (Ursus arctos): A Review and New Management Tool. PLoS ONE 11, e0141983.

Frey, K., Tyers, D., Haroldson, M., Servheen, C., Bruscino, M., Gunther, K., Herring, N., 2011. Fatality of Mr. Brian Matayoshi from a bear attack on the Wapiti Lake trail in Yellowstone National park on July 6, 2011. Board of Review Recommendation Report, Yellowstone National Park, USA.

Gallagher, A. J., Vianna, G. M., Papastamatiou, Y. P., Macdonald, C., Guttridge, T. L., Hammerschlag, N., 2015. Biological effects, conservation potential, and research priorities of shark diving tourism. Biol. Conserv. 184, 365-379.

Geffroy, B., Samia, D.S., Bessa, E., Blumstein, D.T., 2015. How Nature-Based Tourism Might Increase Prey Vulnerability to Predators. Trends Ecol. Evol. 30, 755-765.

Ghosh, N., Uddhammar, E., 2013. Tiger, Lion, and Human Life in the Heart of Wilderness: Impacts of Institutional Tourism on Development and Conservation in East Africa and India. Conserv. Soc. 11, 375.

Grinath, J.B., Inouye, B.D., Underwood, N., 2015. Bears benefit plants via a cascade with both antagonistic and mutualistic interactions. Ecol. Lett. 18, 164-173.

Grünewald, C., Schleuning, M., Böhning-Gaese, K., 2016. Biodiversity, scenery and infrastructure: Factors driving wildlife tourism in an African savannah national park. Biol. Conserv. 201, 60-68.

Gunther, K.A., 1992. Changing problems in bear management: Yellowstone National Park twenty years after the dumps. Proceedings of the ninth annual international bear conference, Missoula, Montana, USA.

Gunther, K.A., Bruscino, M.T., Cain, S., Hanauska-Brown, L., Frey, K., Haroldson, M.A. Schwartz, C.C., 2002. Grizzly bear-human conflicts and management actions in the greater Yellowstone Ecosystem 2001. Interagency grizzly bear committee Yellowstone ecosystem subcommittee report, Yellowstone National Park, Wyoming, USA.

Harding, L., 2014. What Good Is a Bear to Society? Soc. Anim. 22, 174-193.

Haroldson, M.A., Gunther, K.A., 2013. Roadside bear viewing opportunities in Yellowstone National Park: characteristics, trends, and influence of whitebark pine. Ursus 24, 27-41.

Herrero, S., 2002. Bear attacks: their causes and avoidance. Revised edition. Lyons and Burford, New York, New York, USA. 
Herrero, S., Smith, T., DeBruyn, T.D., Gunther, K., Matt, C.A., 2005. From the field: brown bear habituation to people-safety, risks, and benefits. Wildl. Soc. Bull. 33, 1-12.

Hilderbrand, G.V., Hanley, T.A., Robbins, C.T., Schwartz, C.C., 1999. Role of brown bears (Ursus arctos) in the flow of marine nitrogen into a terrestrial ecosystem. Oecologia 121, 546-550.

Hites, R.A., Foran, J.A., Carpenter, D.O., Coreen Hamilton, M., Knuth, B.A., Schwager, S.J., 2004. Global assessment of organic contaminants in farmed salmon. Science 303, 226-229.

Hopkins III, J.B., Herrero, S., Shideler, R.T., Gunther, K.A., Schwartz, C.C., Kalinowski, S.T., 2010. A proposed lexicon of terms and concepts for human-bear management in North America. Ursus 21, 154-168.

Jenner, P., Smith, C., 1992. The tourism industry and the environment. Special Report No. 2453, Economist Intelligence Unit, London.

Jerina, K., Krofel, M., Stergar, M., Videmšek, U., 2012. Factors affecting brown bear habituation to humans: a GPS telemetry study. Final report-summary for users. University of Ljubljana, Biotechnical Faculty, Ljubljana.

Johansson, M., Karlsson, J., Pederson, E., Flykt, A., 2012. Factors governing human fear of brown bear and wolf. Hum. Dimens. Wildl. 17, 58-74.

Karamanlidis, A., Kavčič, I., Majić Skrbinšek, A., Bernardić, L., Blažič, M., Huber, Đ., Reljić, S. 2016. Non-consumptive use of brown bears in tourism: guidelines for responsible practices. Life DinAlp Bear Project. University of Ljubljana, Ljubljana.

Kavčič, I., Adamič, M., Kaczensky, P., Krofel, M., Jerina, K., 2013. Supplemental feeding with carrion is not reducing brown bear depredations on sheep in Slovenia. Ursus 24, 111-119.

Kavčič, I., Adamič, M, Kaczensky, P., Krofel, M., Kobal, M., Jerina, K., 2015. Fast food bears: brown bear diet in a human-dominated landscape with intensive supplemental feeding. Wildl. Biol. 21, 1-8.

Kavčič, I., 2016. Impacts of supplemental feeding and other anthropogenic food sources on the brown bear (Ursus arctos) activity. PhD thesis, University of Ljubljani, Biotehniška fakulteta, Ljubljana, Slovenia (in Slovenian).

Keniger, L.E., Gaston, K.J., Irvine, K.N., Fuller, R.A., 2013. What are the benefits of interacting with nature? Int. J. Environm. Res. Publ. Health 10, 913-935.

Kie, J.G., 1999. Optimal foraging and risk of predation: effects on behavior and social structure in ungulates. J. Mammal. 80, 1114-1129.

Knight, J., 2009. Making Wildlife Viewable: Habituation and Attraction. Soc. Anim. 17, 167-184. 
Kojola, I., Heikkinen, S., 2012. Problem brown bears Ursus arctos in Finland in relation to bear feeding for tourism purposes and the density of bears and humans. Wildl. Biol. 18, 258-263.

Kollmuss, A., Agyeman, J., 2002. Mind the Gap: Why do people act environmentally and what are the barriers to pro-environmental behavior? Environm. Edu. Res. 8, 239-260.

Krofel, M., Jonozovič, M., Jerina, K., 2012a. Demography and mortality patterns of removed brown bears in a heavily exploited population. Ursus $23,91-103$.

Krofel, M., Kos, I., Jerina, K., 2012b. The noble cats and the big bad scavengers: effects of dominant scavengers on solitary predators. Behav. Ecol. Sociobiol. 66, 12971304.

Krofel, M., Jerina, K., 2016. Mind the cat: Conservation management of a protected dominant scavenger indirectly affects an endangered apex predator. Biol. Conserv. 197, 40-46.

Krofel, M., Špacapan, M., Jerina, K., In press. Winter sleep with a room service: denning behaviour of brown bears with access to anthropogenic food. J. Zool.

Lindsey, P.A., Alexander, R., Mills, M.G.L., Romanach, S., Woodroffe, R., 2007. Wildlife viewing preferences of visitors to protected areas in South Africa: implications for the role of ecotourism in conservation. J. Ecotourism 6, 19-33.

Lindsey, P., Havemann, C.P., Lines, R.M., Price, A.E., Retief, T.A., Rhebergen, T., Romañach, S.S., 2013. Benefits of wildlife-based land uses on private lands in Namibia and limitations affecting their development. Oryx 47, 41-53.

López-Bao, J.V., Rodríguez, A., Palomares, F., 2009. Competitive asymmetries in the use of supplementary food by the endangered Iberian lynx (Lynx pardinus). PloS one, 4, e7610.

López-Bao, J.V., Rodríguez, A., Palomares, F., 2010. Abundance of wild prey modulates consumption of supplementary food in the Iberian lynx. Biol. Conserv. 143, 1245-1249.

López-Bao, J.V., Palomares, F., Rodríguez, A., Ferreras, P., 2011. Intraspecific interference influences the use of prey hotspots. Oikos 120, 1489-1496.

Lovelock, J., 2006. The revenge of Gaia: Earth's climate in crisis and the fate of humanity. New York, NY: Basic Books.

MacHutchon, A.G., Himmer, S., Davis, H., Gallagherl, M., 1995. Temporal and spatial activity patterns among coastal bear populations. Ursus 10, 539-546.

Macmillan, D.C., Phillip, S., 2008. Consumptive and non-consumptive values of wild mammals in Britain. Mamm. Rev. 38, 189-204. 
Majić Skrbinšek, A., Krofel, M., 2015. Defining, preventing, and reacting to problem bear behaviour in Europe. Technical report. Institute of Applied Ecology (Rome, Italy). Report to DG Environment, European Commission, Bruxelles.

Massé, S., Dussault, C., Ibarzabal, J., 2014. How artificial feeding for tourism-watching modifies black bear space use and habitat selection. J. Wildl. Manage. 78, 1228-1238.

Matutinovic', I., 2012. The prospects of transition to sustainability from the perspective of environmental values and behaviors in the EU 27 and globally. Int. J. Sust. Devel. World Ecol. 19, 526-535.

McCullough, D.R., 1982. Behavior, Bears, and Humans. Wildlife Society Bulletin 10, $27-$ 33.

Miller, S.M., McCollum, D., 1997. Less may mean more: maximizing the economic, environmental, and social benefits from Alaska's visitor industry. Online at: http:// www.dced.state.ak.us/cbd/toubus/lessmay.htm (accessed: 10 October 2001).

Miller, S.M., Miller, S.D., McCollum, D.W., 1998. Attitudes toward and relative value of Alaskan brown and black bears to resident voters, resident hunters, and nonresident hunters. Ursus 10, 357-376.

Millspaugh, J.J., Washburn, B.E., 2004. Use of fecal glucocorticoid metabolite measures in conservation biology research: considerations for application and interpretation. Gen. Comp. Endocr. 138, 189-199.

Millspaugh J.J., Woods, R.J., Hunt, K.E., Raedeke, K.J., Brundige, G.C., Washburn, B.E., Wasser, S.K., 2001. Fecal glucocorticoid assays and the physiological stress response in elk. Wildl. Soc. Bull. 29, 899-907.

Moen, G.K., Støen, O.G., Sahlén, V., Swenson, J.E., 2012. Behaviour of solitary adult Scandinavian brown bears (Ursus arctos) when approached by humans on foot. PLoS One 7, e31699.

Mohorović, M., Krofel, M., Jerina, K., In press. Brown bear (Ursus arctos) under the influence of human enchroachment on habitats. Acta Silvae et Ligni.

Mossaz, A., Buckley, R.C., Castley, J.G., 2015. Ecotourism contributions to conservation of African big cats. J. Nature Conserv. 28, 112-118.

Murray, M.H., Becker, D.J., Hall, R.J., Hernandez, S.M. 2016. Wildlife health and supplemental feeding: A review and management recommendations. Biol. Conserv. http://dx.doi.org/10.1016/j.biocon.2016.10.034

Naves, J., Fernández-Gil, A., Delibes, M., 2001. Effects of recreation activities on a brown bear family group in Spain. Ursus 12, 135-140. 
1000

1001

1002

1003

1004

1005

1006

1007

1008

1009

1010

1011

1012

1013

1014

1015

1016

1017

1018

1019

1020

1021

1022

1023

1024

1025

1026

1027

Nellemann, C., Støen, O., Kindberg, J., Swenson, J., Vistnes, I., Ericsson, G., Katajisto, J., Kaltenborn, B., Martin, J., Ordiz, A., 2007. Terrain use by an expanding brown bear population in relation to age, recreational resorts and human settlements. Biol. Conserv. 138, 157-165.

Nevin, O.T., Gilbert, B.K., 2005a. Perceived risk, displacement, and refuging in brown bears: positive impacts of ecotourism? Biol. Conserv. 121, 611-622.

Nevin, O.T., Gilbert, B.K., 2005b. Measuring the cost of risk avoidance in brown bears: Further evidence of positive impacts of ecotourism. Biol. Conserv. 123, 453460.

Nevin, O.T., Swain, P., Convery, I., 2014. Bears, Place-making, and Authenticity in British Columbia. Nat. Area. J. 34, 216-221.

von der Ohe, C.G., Wasser, S.K., Hunt, K.E., Servheen, C., 2004. Factors Associated with Fecal Glucocorticoids in Alaskan Brown Bears (Ursus arctos horribilis). Physiol. Biochem. Zool. 77, 313-320.

Okello, M.M., Manka, S.G., D'Amour, D.E., 2008. The relative importance of large mammal species for tourism in Amboseli National Park, Kenya. Tourism Manage. 29, 751-760.

Olson, T.L., 1993. Resource partitioning among brown bears at Brooks River in Katmai National Park and Preserve, Alaska. Thesis, Utah State University, Logan, USA.

Olson, T.L., Gilbert, B.K., Squibb, R.C., 1997. The effects of increasing activity on brown bear use of an Alaskan river. Biol. Conserv. 82, 95-99.

Olson, T.L. 1998. Brown bear diurnal activity and human use: A comparison of two salmon streams. Ursus $10,547-555$.

Orams, M.B., 2002. Feeding wildlife as a tourism attraction: a review of issues and impacts. Tourism Manage. 23, 281-293.

Ordiz, A., Rodríguez, C., Naves, J., Fernández, A., Huber, D., Kaczensky, P., Mertens, A., Mertzanis, Y., Mustoni, A., Palazón, S., Quenette, P.Y., Rauer, G., Swenson, J.E., 2007. Distance-based criteria to identify minimum number of brown bear females with cubs in Europe. Ursus 18, 158-167.

Ordiz, A., Støen, O.-G., Delibes, M., Swenson, J.E., 2011. Predators or prey? Spatiotemporal discrimination of human-derived risk by brown bears. Oecologia 166, 59-67.

Ordiz, A., Støen, O.-G., Sæbo, S., Kindberg, J., Swenson, J.E., 2012. Do bears know they are being hunted? Biol. Conserv. 152, 21-28.

Ordiz, A., Støen, O.-G., Sæbø, S., Sahlén, V., Pedersen, B.E., Kindberg, J., Swenson, J.E., 2013. Lasting behavioural responses of brown bears to experimental encounters with humans. J. Appl. Ecol. 50, 306-314. 
Ordiz, A., Kindberg, J., Sæbø, S., Swenson, J.E., Støen, O.-G., 2014. Brown bear circadian behaviour reveals human environmental encroachment. Biol. Conserv. 173, 1-9.

Palmer, L., 2003. Unbearable: bear-viewing boom could take a toll on Alaska's great grizzlies. Alaska 69, 26-31.

Penteriani, V., Delgado, M.M., Melletti, M., 2010. Don't feed the bears! Oryx 44, 169170.

Penteriani, V., Delgado, M.M., Pinchera, F., Naves, J., Fernández-Gil, A., Kojola, I., Norberg, H. Frank, J., Fedriani, J.M., Sahlén, V., Støen, O.-G., Swenson, J.E., Pellegrini, M., Wabakken, P., Herrero, S., López-Bao, J.V., 2016. Human behaviour triggers large carnivore attacks in developed countries. Sci. Rep. 6, 20552.

Reding, R., 2015. Effects of diversionary feeding on life history traits of brown bears. Master thesis. University of Natural Resources and Life Sciences, Vienna.

Reynolds, P.C., Braithwaite, D., 2001. Towards a conceptual framework for wildlife tourism. Tourism Manage. 22, 31-42.

Richardson, L., Rosen, T., Gunther, G., Schwartz, C., 2014. The economics of roadside bear viewing. J. Environm. Managem. 140, 102-110.

Robelia, B., Murphy, T., 2012. What do people know about key environmental issues? A review of environmental knowledge surveys. Environ. Edu. Res. 18, 299321.

Rode, K.D., Robbins, C.T., Shipley, L.A., 2001. The constraints on herbivory by bears. Oecologia 128, 62-71.

Rode, K.D., Farley, S.D., Robbins, C.T., 2006a. Behavioral responses of brown bears mediate nutritional effects of experimentally introduced tourism. Biol. Conserv. $133,70-80$.

Rode, K.D., Robbins, C.T., Farley, S.D., 2006b. Sexual dimorphism, reproductive strategy, and human activities determine resource use by brown bears. Ecology 87, 2636-2646.

Rode, K.D., Farley, S.D., Fortin, J., Robbins, C.T., 2007. Nutritional consequences of experimentally introduced tourism in brown bears. J. Wildl. Manage. 71, 929939.

Sahlén, V., Ordiz, A., Swenson, J.E., Støen, O.G., 2015. Behavioural differences between single Scandinavian brown bears (Ursus arctos) and females with dependent young when experimentally approached by humans. PloS ONE 10, e0121576.

Sato, C.F., Wood, J.T., Lindenmayer, D.B. 2013. The effects of winter recreation on alpine and subalpine fauna: a systematic review and meta-analysis. PLoS ONE 8, e64282. 
Selva, N., Berezowska-Cnota, T., Elguero-Claramunt, I., 2014. Unforeseen effects of supplementary feeding: ungulate baiting sites as hotspots for ground-nest predation. Plos ONE 9, e90740.

Shackley, M. 1996. Wildlife tourism. London: International Thomson Business Press.

Skibins, J.C., Hallo, J.C., Sharp, J.L., Manning, R.E., 2012. Quantifying the role of viewing the Denali "big 5" in visitor satisfaction and awareness: conservation implications for flagship recognition and resource management. Hum Dimens Wildl 17, 112-128.

Smith, T.S., Johnson, A., 2004. Modeling the Effects of Human Activity on Katmai Brown Bears (Ursus arctos) through the Use of Survival Analysis. Arctic 57, 160165.

Smith, T.S., Herrero, S., DeBruyn, T.D., 2005. Alaskan brown bears: habituation and humans. Ursus 16, 1-10.

Sorensen, A., van Beest, F.M., Brook, R.K. 2014. Impacts of wildlife baiting and supplemental feeding on infectious disease transmission risk: a synthesis of knowledge. Prev. Vet. Med. 113, 356-363.

Starmer-Smith, C. (2004, November 6). Ecofriendly tourism on the rise. Daily Telegraph Travel, 6.

Steven, R., Pickering, C., Castley, J.G., 2011. A review of the impacts of nature based recreation on birds. J. Environ. Manage. 92, 2287-2294.

Steyaert, S.M.J.G., Kindberg, J., Jerina, K., Krofel, M., Stergar, M., Swenson, J.E., Zedrosser, A., 2014. Behavioral correlates of supplementary feeding of wildlife: Can general conclusions be drawn? Basic Appl. Ecol. 15, 669-676.

Støen, O. G., Ordiz, A., Evans, A. L., Laske, T. G., Kindberg, J., Fröbert, O., Swenson, J.E., Arnemo, J.M., 2015. Physiological evidence for a human-induced landscape of fear in brown bears (Ursus arctos). Physiol. Behav. 152, 244-248.

Stringham, S., Bryant, A., 2015. Distance-dependent effectiveness of diversionary bear bait sites. Hum. Wildl. Interact. 9, 229-235.

Swenson, J.E., Gerstl, N., Dahle, B., Zedrosser, A. 2000. Action plan for the conservation of the brown bear (Ursus arctos) in Europe. Convention on the Conservation of European Wildlife and Natural Habitats (Bern Convention), Nature and Environment, No. 114

Tapper, R., 2006. Wildlife watching and tourism: a study on the benefits and risks of a fast growing tourism activity and its impacto $n$ species. UNEP/CMS Secreteriat, Bonn, Germany.

Taylor, B. R., 2010. Dark green religion: Nature spirituality and the planetary future. Berkeley, CA: University of California Press. 
Taylor, A.R., Knight, R.L., 2003. Wildlife responses to recreation and associated visitor perceptions. Ecol. Appl. 13, 951-963.

The International Ecotourism Society (TIES), 2015. Definition revised. Retrieved from https://www.ecotourism.org/what-is-ecotourism (accessed 22 December 2016).

Tisdell, C., Wilson, C., 2001. Wildlife-based tourism and increased support for nature conservation financially and otherwise: evidence from sea turtle ecotourism at Mon Repos. Tour. Econ. 7, 233-249.

Tisdell, C., Wilson, C., 2004. Economics of wildlife tourism. In Higginbottom, K. (ed.), Wildlife tourism: impacts, management, and planning, pp., 145-166. Common Ground Publishing, Altona, Australia.

Tollefson, T.N., Matt, C., Meehan, J., Robbins, C.T., 2005. Research notes: quantifying spatiotemporal overlap of Alaskan brown bears and people. J. Wildl. Manage. 69, 810-817.

Tolvanen, A., Kangas, K., 2016. Tourism, biodiversity and protected areas-Review from northern Fennoscandia. J. Environ. Manage. 169, 58-66.

Turner, C.N. 2012. Determining the effectiveness of park management strategies at a coastal brown bear viewing site in Katmai National Park, Alaska. M.Sc. Thesis, Royal Roads University.

United Nations World Tourism Organisation, 2014. Towards measuring the economic value of wildlife watching tourism in Africa. Briefing paper, UN WTO, Madrid, Spain.

Whittaker, D., Knight, R.L., 1998. Understanding wildlife responses to humans. Wildl. Soc. Bull. 26, 312-317.

Wilker, G.A., Barnes, V.G. Jr., 1998. Responses of brown bears to human activities at O'Malley River, Kodiak Island, Alaska. Ursus 10, 557-561.

Wilmot, K., Frey, K., Tyers, D., Haroldson, M., van Manen, F., Servheen, C., DeBolt, B., Thompson,D., Bjornlie, D., Gunther, K., 2016. Fatality of Mr. Lance Crosby from a bear attack on Elephant Black Mountain in Yellowstone National park on August 6, 2015. Board of Review Recommendation Report, Yellowstone National Park, USA.

Wilson, M.F., Gende, S.M., 2004. Seed dispersal by brown bears, Ursus arctos, in southeastern Alaska. Can. Field Nat. 118, 499-503.

Zager, P., Beecham, J., 2006. The role of American black bears and brown bears as predators on ungulates in North America. Ursus 17, 95-108. 
Fig. 1

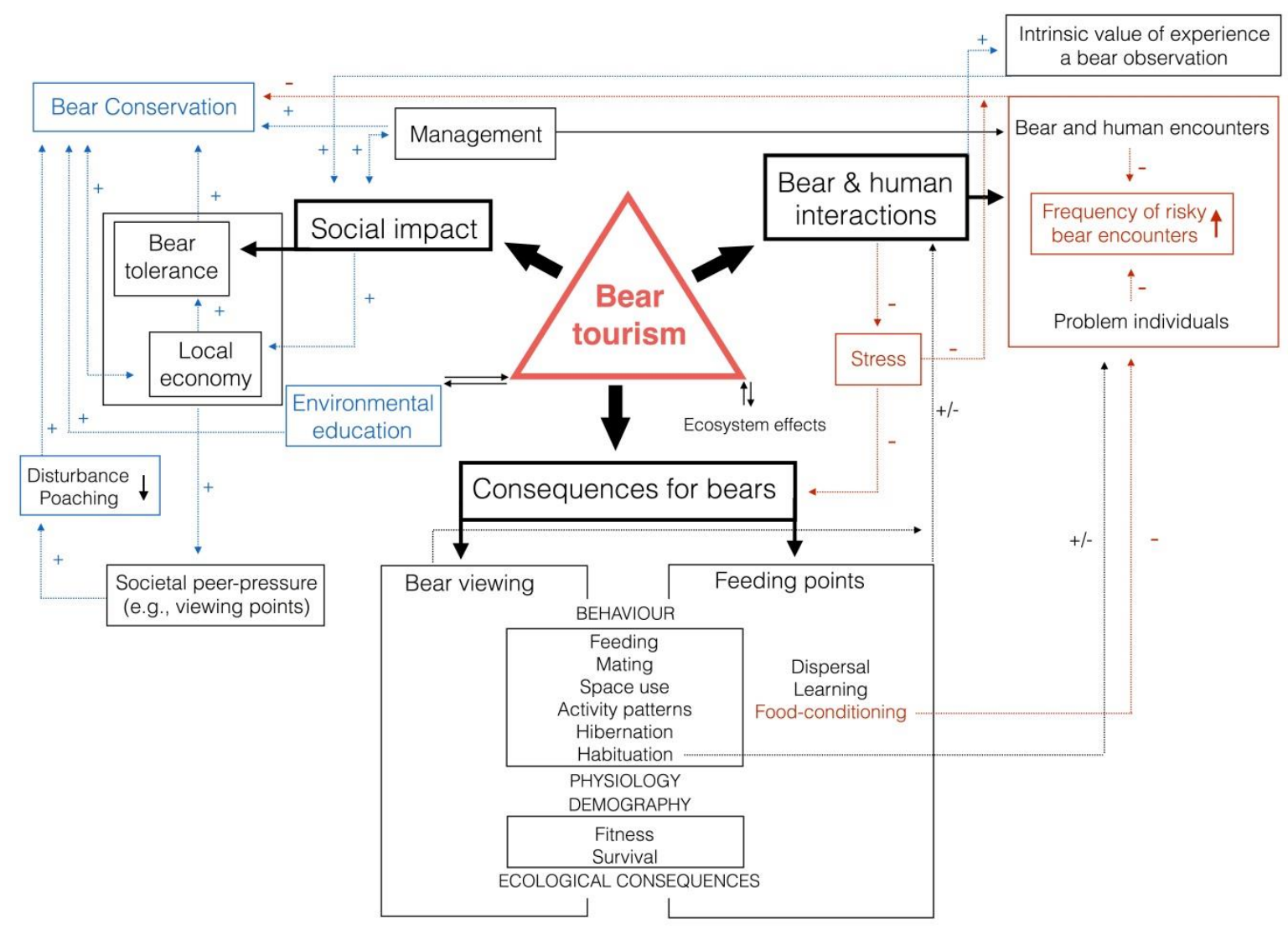

Figure 1. Conceptual framework of bear ecotourism. Conceptual framework and flowchart of bear ecotourism and hypothesized positive and negative consequences of ecotourism for bears, bear-human interactions and social impact. Blue and red arrows indicate positive and negative confirmed/expected impacts of bear viewing, respectively. Black arrows denote relationships where both negative and positive impacts might be expected. 
Fig. 2
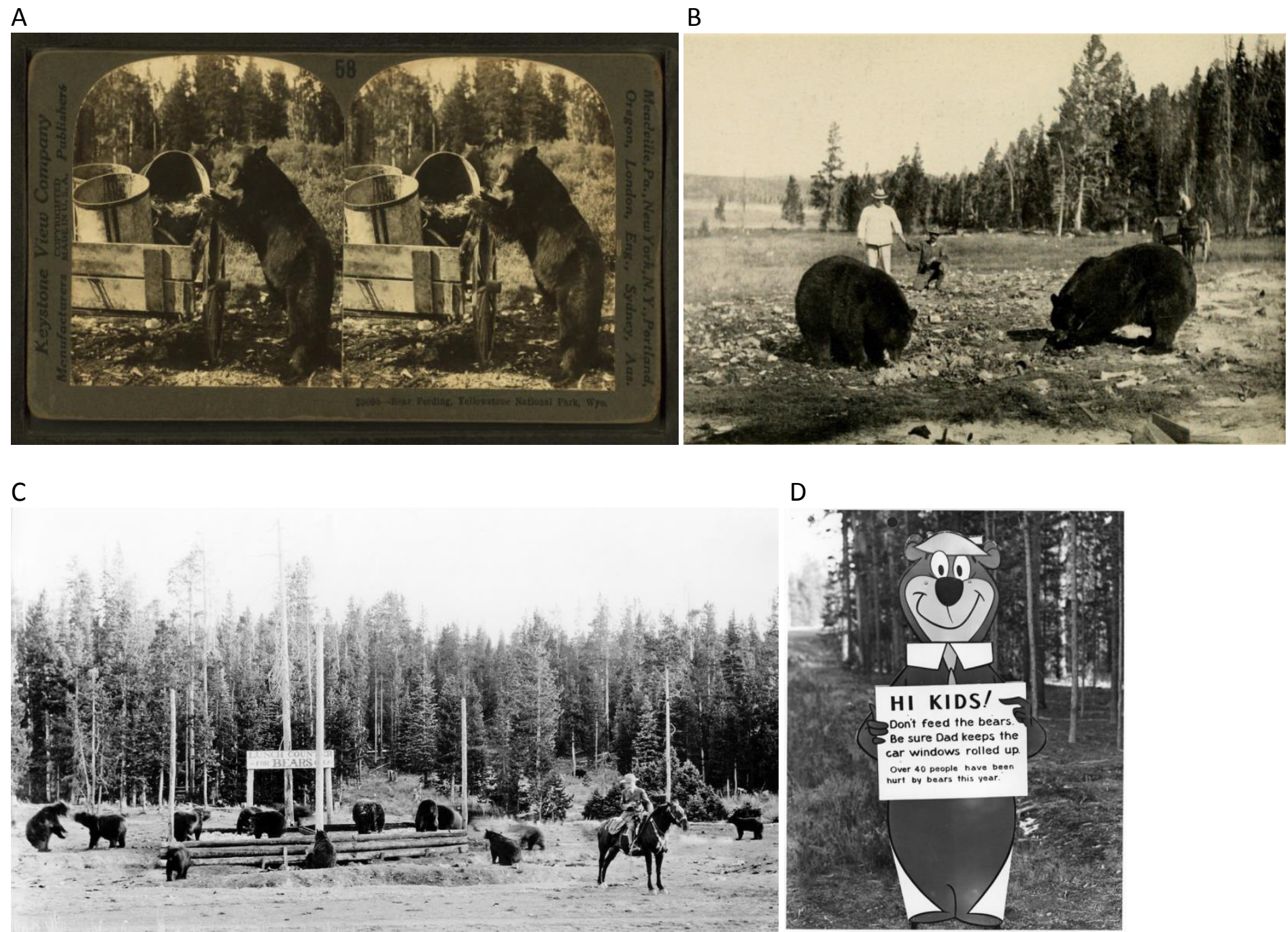
Figure 2. Bear feeding at the beginning of the $20^{\text {th }}$ century. $A$ and $B$ : Images of bear feeding at the beginning of the $20^{\text {th }}$ century in Yellowstone National Park, USA. C: A signboard to remind visitors not to feed bears dating from the beginning of the 1960's, when negative consequences of bear feeding started to become evident in Yellowstone. (A: downloaded from Wikimedia Commons

https://commons.wikimedia.org/feeding Yellowstone.png; Original source: Robert N. Dennis collection of stereoscopic views. / United States. / States / Wyoming. / Stereoscopic views of Yellowstone National Park, Wyoming; published: ca. 18951920?). (B: downloaded from Wikimedia Commons https://commons.wikimedia.org/American big game in its haunt.jpg C: downloaded from Yellowstone National Park / Flickr in the Public Domain https://www.flickr.com/photos/yellowstonenps/24773233536/“Lunch Counter - For Bears Only" at Old Faithful, southeast of the upper Hamilton Store, and Ranger Naturalist Walter Phillip Martindale; Photographer unknown; 1921- mid 1930s. (D: downloaded from Wikimedia Commons https://commons.wikimedia.org/wiki/File:Yogi Bear feed the bears.jpg; Original source: U.S. National Archives and Records Administration). 
Fig. 3

A

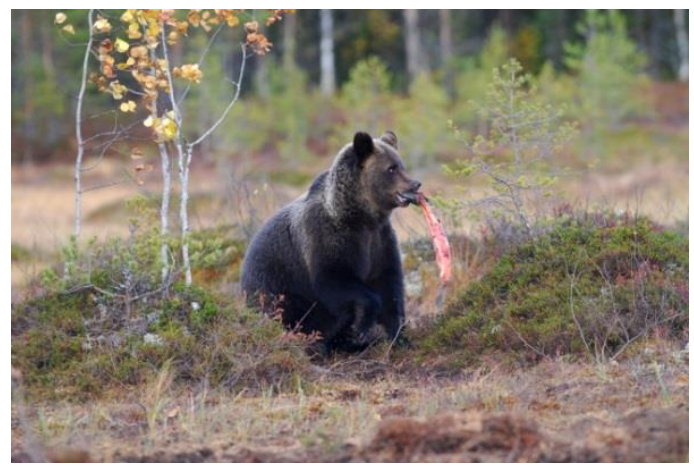

C

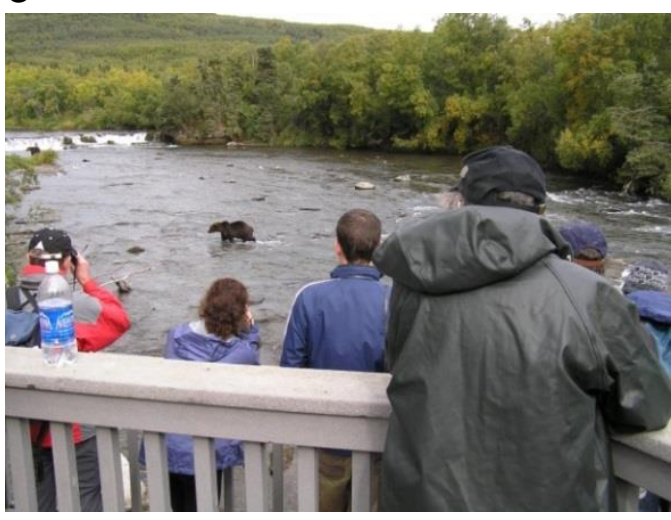

$E$

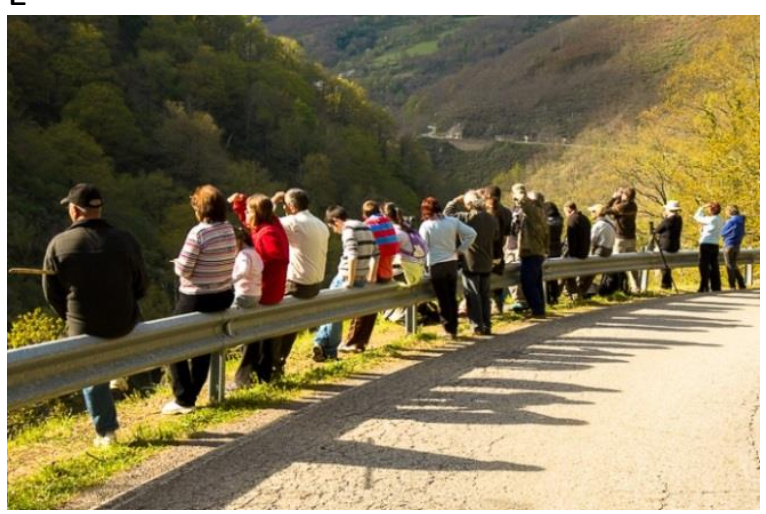

B

D
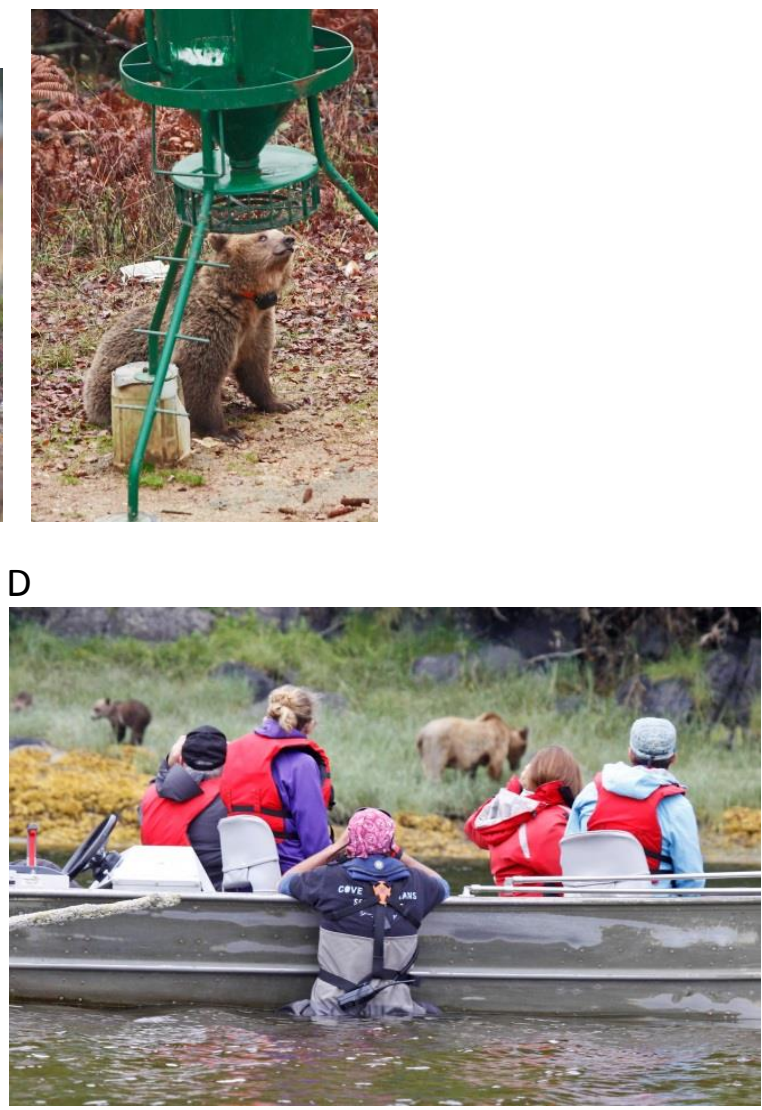

$\mathrm{F}$

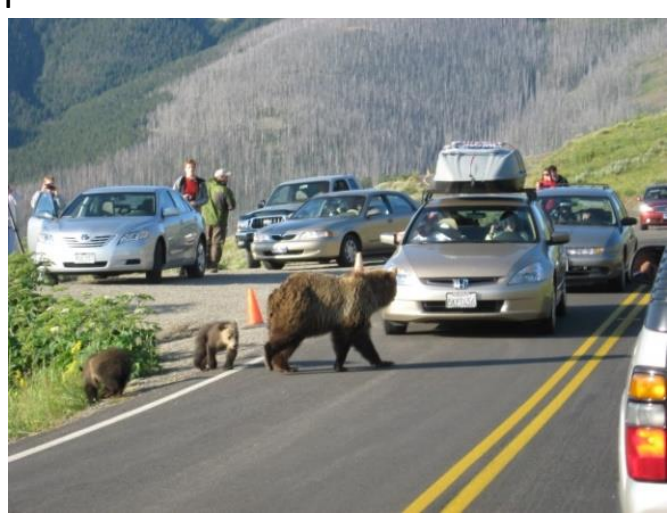

Figure 3. Bear viewing in Europe and North America. Some typical situations linked to bear viewing in Europe and North America. A-D show pre-planned activities at defined sites, whereas E-F are opportunistically occurring. A (Image: V. Penteriani). Bear feeding on farmed salmon in a clearcutting at a Finnish brown bear viewing site. B. Radio-collared female bear at a bear feeding site with an automatic feeder with corn in Slovenia (Image: M. Krofel). C. A regulated North American viewing spot where bears concentrate during salmons runs (Image: S. Herrero). D. Tourists accompanied by a 
professional guide observing a bear family feeding on mussels and barnacles in British Columbia, Canada (Image: M. Krofel). E. Random aggregations of people near bears in NW Spain (Image: C. Rodríguez del Valle). F. An example of the so-called 'bear traffic jam' due to random bear sightings along Yellowstone roads (Image: K. Gunther). 
Legend of the Supplementary Material_ Table A1.

Locations of current bear viewing sites in North America and Europe/Russia and main features of bear viewing practices. 